\title{
Levels of Heavy Metals in Different Tissues of Pigeon (Columba livia) of Bangladesh for Safety Assessment for Human Consumption
}

\author{
Aleya Begum and Sabrina Sehrin \\ Department of Zoology, University of Dhaka, Dhaka 1000, Bangladesh
}

\begin{abstract}
Heavy metal pollution was reported in commercially valuable and edible pigeon (Columba livia, Gmelin 1789) of Bangladesh. The concentrations of $\mathrm{As}, \mathrm{Pb}, \mathrm{Cd}, \mathrm{Cr}, \mathrm{Zn}$, and $\mathrm{Cu}$ were investigated in the muscle, intestine, kidney, gizzard and liver. For this 60 C. livia were selected from five locations to assess the degree of pollution by heavy metals in pigeon. Significant differences in heavy metal concentrations were observed among different tissues, but not among the locations. The ranges of the measured concentrations ( $\mu \mathrm{g} / \mathrm{g}$ dry weight) in the tissues of C. livia were as follows: arsenic: $(0.01-0.04),(0.02-0.04),(0.02-0.08),(0.02-0.04)$ and $(0.03-0.07)$; lead: $(0.21-0.56)$, (0.07-1.64), (0.62-1.97), (0.41-0.79) and (1.47-5.75); cadmium: $(0.01-0.05),(0.13-0.97),(0.53-1.85),(0.32-$ $0.78)$ and (0.22-2.41); chromium: (0.25-1.93), (1.18-5.90), (1.59-4.40), (1.15-1.65) and (1.38-8.36); zinc: (73.22-256.56), (95.62-130.75), (19.87-67.18), (108.99-124.77) and (159.80-280.76); copper: (3.44-7.64), (5.30-17.50), (8.72-16.55), (1.19-34.42) and (26.09-43.60) in the muscle, intestine, kidney, gizzard, and liver, respectively. This research showed that the liver appeared to be the main storage site of heavy metals, while the muscle had the lowest levels of the analyzed metals. The concentrations of metal in the muscles were not found to exceed the acceptable level for human consumption.
\end{abstract}

Key words: Bioaccumulation, Heavy metal, Pollution, Pigeon tissues, Bangladesh

\section{Introduction}

Large quantities of pollutants have continuously been introduced into different cities as a consequence of anthropogenic activities such as urbanization, traffic, and industrial processes. Heavy metals are considered as critical contaminants in the environment, due to their high potential to enter and accumulate in food chains (Olojo et al. 2005; Erdoğrul and Erbilir 2007). The main sources of heavy metal pollution are the agriculture, industry and mining activities (Singh et al. 2007). Some of these metals including arsenic, lead, cadmium, chromium are toxic to living organisms even at quite low concentrations, while others such as copper and zinc are biologically essential and natural constituents of the aquatic ecosystems and become toxic only at very high concentrations (Cohen et al. 2001; Storelli et al. 2006). This has led to the development of monitoring schemes aimed at directly measuring the levels of contaminants in various organisms, and biomonitoring schemes that use indicator species to estimate the levels in other parts of the ecosystem. Earlier studies have led to an increased interest in the use of birds as monitors of geographical, historical and global patterns of heavy metal pollution in the environment, as they occupy a wide range of trophic levels in different food chains (Burger et al. 1999; Eens et al. 1999). Birds are easier to study and monitor than other bioindicators, making them ideal for the monitoring purposes (Sundlof et al. 1994; Cohen et al. 2000).

Among possible biomonitoring species, birds have been widely used to assess environmental contamination, and in urban and rural environments, the usefulness of the feral pigeon (C. livia) as a bioindicator of pollution has been assessed over the last decades (Nam et al. 2004; Schilderman et al. 1997). These metropolitan sedentary birds forage on the ground and present abundant, stable populations, mostly associated with human activities. Their atmospheric exposure in the urban environment is similar to that of the human population and, consequently, pigeons have been extensively used to monitor heavy metal pollution (Hutton and Goodman 1980; Nam and Lee 2006; Schilderman et al. 1997). However, heavy metals pollution in tissues of pigeon has become an important

Correspondence to: Aleya Begum, E-mail: aleya2000@hotmail.com 
concern worldwide, not only because of the threat to tissues of pigeon, but also due to the health risks associated with tissues of pigeon consumption. Therefore, the problem of heavy metal contamination in tissues of pigeon is increasing global attention.

The aim of this study was to evaluate the bioaccumulation of heavy metals in various tissues, including the muscle, intestine, kidney, gizzard, and liver) of C. livia to gain insight into the distribution of metals in this pigeon to assess indirectly the level of pollution. In addition, as this pigeons are commercially valuable and edible, metal in the muscle tissue were compared with respective maximum permissible limits established by law in order to ascertain whether this food could be considered suitable for human consumption.

\section{Materials and Methods}

Sample collection: The 60 pigeons were collected from 5 different locations (Keranigonj, Norsinghdi, Mymensingh, Sirajgonj and Comilla) of Bangladesh. Special care was taken to make sure that the pigeons were approximately of similar size and weight. The pigeons were collected on monthly basis at regular intervals, from February 2010 to January 2011. The samples were put in plastic bag/containers and transported to the laboratory of the Department of Zoology, University of Dhaka on the same day. Different organs of pigeon body such as muscle, intestine, gizzard, liver, and kidney were collected and frozen. These frozen samples were cleaned and washed with deionized water. Sample tissue were chopped into pieces with the aid of a stainless steel knife which had been cleaned by acetone and hot distilled water prior to use. These samples were dried in an oven at $65^{\circ} \mathrm{C}$ for 48 hours. The dried samples were powdered and homogenized. The sample powders were dried at $105^{\circ} \mathrm{C}$ in an oven until a constant weight was obtained (dry weight). Finally, the sample powders were preserved in clean and dry polyethene bottle for subsequent analyses.

Chemical analysis: Triplicates of accurately weighted about $2.0 \mathrm{~g}$ (dry weight) portions of the tissues of pigeons were treated with $10 \mathrm{ml}$ of $14 \mathrm{M}$ nitric acid, $5 \mathrm{ml}$ of $13 \mathrm{M}$ perchloric acid and $5 \mathrm{ml}$ of demineralized water in a Teflon decomposition vessel. The vessel was put in a stainless steel container and heated for $2 \mathrm{~h}$ at $150{ }^{\circ} \mathrm{C}$ in an electric oven. After decomposition, the solution was evaporated down to about $5 \mathrm{ml}$ in a Teflon beaker by heating with a hot plate. Finally, the solution was transferred to a $100 \mathrm{ml}$ volumetric flask and diluted upto the mark with demineralized water. The standard solutions were prepared in $0.1 \mathrm{~N}$ perchloric acid. The aqueous digest was analyzed directly using a Pye Unicam SP-2900 flame Atomic Absorption Spectometer for $\mathrm{Pb}, \mathrm{Cd}, \mathrm{Cr}, \mathrm{Zn}$ and $\mathrm{Cu}$, and Hydride Generation Atomic Absorption Spectometer (HG-AAS) for As (Begum et al. 2005).

The accuracy of the analytical procedure was checked by analyzing the standard reference material (National Research Council, Canada; DORM-2 dogfish muscle). The elemental concentrations determined in standard reference materials were in good agreement with the certified values, as shown in Table 1. All data were expressed in $\mu \mathrm{g} / \mathrm{g}$ dry weight (dw).

Table 1. Comparison of experimental values with certified values of standard reference materials DOMR-2 (Dogfish muscle) ( $\mu \mathrm{g} / \mathrm{gm}$ dry weight basis).

\begin{tabular}{lccc}
\hline Metal & $\begin{array}{c}\text { Concentration } \\
\text { certified value }\end{array}$ & $\begin{array}{c}\mu \mathrm{g} / \mathrm{gm} \\
\text { our value* }^{*}\end{array}$ & $\begin{array}{c}\text { Deviation } \\
(\%)\end{array}$ \\
\hline $\mathrm{As}$ & $18.00 \pm 1.10$ & $17.56 \pm 0.52$ & 2.51 \\
$\mathrm{~Pb}$ & $0.065 \pm 0.007$ & $0.067 \pm 0.021$ & 2.99 \\
$\mathrm{Cd}$ & $0.043 \pm 0.008$ & $0.041 \pm 0.014$ & 4.88 \\
$\mathrm{Cr}$ & $34.70 \pm 5.50$ & $35.53 \pm 4.50$ & 2.39 \\
$\mathrm{Zn}$ & $25.60 \pm 2.30$ & $26.37 \pm 2.65$ & 2.92 \\
$\mathrm{Cu}$ & $2.34 \pm 0.16$ & $2.30 \pm 0.15$ & 1.74 \\
\hline
\end{tabular}

*Average of three determination.

\section{Results and Discussion}

Significant differences in concentrations of analyzed heavy metals were observed among different tissues, but not among the locations. This research showed that the liver appeared to be the main site of heavy metal storage, while the muscle had the lowest levels of analyzed metals. Mean concentrations of heavy metals in the muscle, intestine, kidney, gizzard and liver of commercially available edible C. livia are presented in Table 2. The elemental concentrations in the tissues of pigeon did not vary significantly among the five locations. In order to evaluate the elemental concentrations in the pigeon tissues, we compared the measured values with those in the tissues obtained at other places (Torres et al. 2010; Schilderman et al. 1997; Hutton et al. 1980; Nam et al. 2006; Table 3). 
Recent research has suggested that arsenic (As) acts as an endocrine disruptor at extremely low concentrations (Stoica et al. 2000). In the present study, As concentrations were $0.03,0.03,0.04,0.03$, and $0.05 \mu \mathrm{g} / \mathrm{g}$ in the muscle, intestine, kidney, gizzard, and liver, respectively. However, arsenic concentration in different tissues of the pigeon like the muscle and liver have not been extensively studied. The results showing a higher As concentration in the liver than in the muscle, intestine, kidney and gizzard observed in this study is different from the result in Spain (Hutton et al. 1980).

Table 2. Heavy metal concentrations ( $\mu \mathrm{g} / \mathrm{gm}$ dry weight \pm standard deviation) in different organs/tissues of pigeon.

\begin{tabular}{|c|c|c|c|c|c|c|c|}
\hline Tissues & Locations & As & $\mathrm{Pb}$ & $\mathrm{Cd}$ & $\mathrm{Cr}$ & $\mathrm{Zn}$ & $\mathrm{Cu}$ \\
\hline \multirow[t]{7}{*}{ Muscle } & Keranigonj Norsingdhi & 0.02 & 0.37 & 0.03 & 1.93 & 256.56 & 7.64 \\
\hline & Sirajgonj & 0.04 & 0.56 & 0.04 & 0.11 & 156.30 & 5.81 \\
\hline & Mymensingh & 0.04 & 0.27 & 0.04 & 1.59 & 113.40 & 4.68 \\
\hline & Comilla & 0.04 & 0.55 & 0.03 & 0.25 & 73.22 & 3.44 \\
\hline & Range & 0.01 & 0.21 & 0.01 & 0.69 & 129.00 & 5.81 \\
\hline & Mean & $(0.01-0.04)$ & $(0.21-0.56)$ & $(0.01-0.05)$ & $(0.25-1.93)$ & $(73.22-256.56)$ & $(3.44-7.64)$ \\
\hline & & $0.03 \pm 0.001$ & $0.39 \pm 0.029$ & $0.03 \pm 0.006$ & $0.91 \pm 0.086$ & $145.69 \pm 0.00$ & $5.48 \pm 0.00$ \\
\hline \multirow[t]{7}{*}{ Intestine } & Keranigonj Norsingdhi & 0.04 & 1.64 & 0.62 & 1.22 & 130.75 & 16.18 \\
\hline & Sirajgonj & 0.03 & 0.86 & 0.27 & 1.39 & 106.75 & 17.50 \\
\hline & Mymensingh & 0.03 & 0.72 & 0.82 & 1.39 & 109.29 & 5.30 \\
\hline & Comilla & 0.02 & 0.79 & 0.97 & 1.18 & 112.27 & 8.44 \\
\hline & Range & 0.04 & 0.07 & 0.13 & 5.90 & 95.62 & 6.20 \\
\hline & Mean & $(0.02-0.04)$ & $(0.07-1.64)$ & $(0.13-0.97)$ & $(1.18-5.90)$ & $(95.62-130.75)$ & $(5.30-17.50)$ \\
\hline & & $0.03 \pm 0.010$ & $0.82 \pm 0.00$ & $0.56 \pm 0.077$ & $2.22 \pm 0.086$ & $110.94 \pm 0.087$ & $10.72 \pm 0.00$ \\
\hline \multirow[t]{7}{*}{ Kidney } & Keranigonj Norsingdhi & 0.02 & 1.45 & 1.85 & 4.40 & 58.20 & 12.29 \\
\hline & Sirajgonj & 0.02 & 0.62 & 0.62 & 2.65 & 23.84 & 10.38 \\
\hline & Mymensingh & 0.02 & 1.97 & 0.59 & 1.63 & 67.18 & 16.55 \\
\hline & Comilla & 0.08 & 0.79 & 0.55 & 1.59 & 38.10 & 8.72 \\
\hline & Range & 0.04 & 1.02 & 1.03 & 2.09 & 19.87 & 13.69 \\
\hline & Mean & $(0.02-0.08)$ & $(0.62-1.97)$ & $(0.53-1.85)$ & $(1.59-4.40)$ & $(19.87-67.18)$ & $(8.72-16.55)$ \\
\hline & & $0.04 \pm 0.010$ & $1.17 \pm 0.006$ & $0.93 \pm 0.00$ & $2.47 \pm 0.086$ & $41.44 \pm 0.00$ & $12.33 \pm 0.010$ \\
\hline \multirow[t]{7}{*}{ Gizzard } & Keranigonj Norsingdhi & 0.02 & 0.79 & 0.61 & 1.59 & 124.77 & 4.47 \\
\hline & Sirajgonj & 0.04 & 0.44 & 0.36 & 1.63 & 108.99 & 1.19 \\
\hline & Mymensingh & 0.03 & 0.48 & 0.60 & 1.46 & 124.05 & 3.50 \\
\hline & Comilla & 0.02 & 0.41 & 0.78 & 1.15 & 110.35 & 34.42 \\
\hline & Range & 0.04 & 0.59 & 0.32 & 1.65 & 121.37 & 2.02 \\
\hline & Mean & $(0.02-0.04)$ & $(0.41-0.79)$ & $(0.32-0.78)$ & $(1.15-1.65)$ & (108.99-124.77) & $(1.19-34.42)$ \\
\hline & & $0.03 \pm 0.010$ & $0.54 \pm 0.00$ & $0.53 \pm 0.00$ & $1.49 \pm 0.086$ & $117.91 \pm 0.00$ & $9.12 \pm 0.087$ \\
\hline \multirow[t]{7}{*}{ Liver } & Keranigonj Norsingdhi & 0.03 & 1.47 & 1.37 & 1.86 & 159.80 & 26.09 \\
\hline & Sirajgonj & 0.03 & 5.75 & 0.57 & 2.38 & 280.76 & 34.11 \\
\hline & Mymensingh & 0.04 & 3.02 & 2.41 & 1.38 & 210.50 & 34.77 \\
\hline & Comilla & 0.07 & 2.18 & 0.22 & 8.36 & 275.70 & 36.53 \\
\hline & Range & 0.05 & 1.83 & 0.94 & 2.86 & 272.00 & 43.60 \\
\hline & Mean & $(0.03-0.07)$ & $(1.47-5.75)$ & $(0.22-2.41)$ & $(1.38-8.36)$ & $(159.80-280.76)$ & $(26.09-43.60)$ \\
\hline & & $0.05 \pm 0.010$ & $2.85 \pm 0.010$ & $1.10 \pm 0.086$ & $3.37 \pm 0.00$ & $239.75 \pm 0.248$ & $35.02 \pm 0.135$ \\
\hline
\end{tabular}

In the past, the use of $C$. livia to monitor $\mathrm{Pb}$ pollution resulted from the use of alkyl lead as an antiknocking agent in automobile gasoline. Despite the use of lead-free gasoline, a recent study on blood of urban pigeons from the Netherlands revealed that high-traffic emissions are still one of the major $\mathrm{Pb}$ source (Schilderman et al. 1997).
In addition, lead is a ubiquitous pollutant which could find its way into the environment through discharge of industrial wastes from various industries and other sources. In the present study, the highest lead concentration was found in the liver of C. livia $(2.85$ $\mu \mathrm{g} / \mathrm{g})$, while the lowest lead concentration $(0.39 \mu \mathrm{g} / \mathrm{g})$ was 
always evident in the muscle tissues of pigeon. Since, this lead content in the muscle of pigeon corresponded to 0.08 $\mu \mathrm{g} / \mathrm{g}$ wet weight, careful attention should be paid to edible pigeon in Bangladesh.

The highest concentration of $\mathrm{Cd}(1.10 \mu \mathrm{g} / \mathrm{g})$ was observed in the liver of $C$. livia, while the lowest concentration $(0.03 \mu \mathrm{g} / \mathrm{g})$ was detected in the muscle tissue. The same distribution pattern of $\mathrm{Cd}$ was recorded (highest levels in the liver, lowest in the muscle) in other pigeons in spain (Torres et al. 2010). The maximum admissible value for pigeon is $0.05 \mu \mathrm{g} / \mathrm{g}$ wet weight (EU Commission 2001). From our experimental study, it was vividly observed that $\mathrm{Cd}$ in the muscle of pigeon from the different locations of Bangladesh was below the abovediscussed standard values, but long period of accumulation of $\mathrm{Cd}$ in pigeon might still be a health hazard.

Table 3. Comparison of heavy metal concentrations ( $\mu \mathrm{g} / \mathrm{gm}$, dry weight) in different tissues of pigeon.

\begin{tabular}{|c|c|c|c|c|c|c|c|c|}
\hline Location & Tissues & As & $\mathrm{Pb}$ & $\mathrm{Cd}$ & $\mathrm{Cr}$ & $\mathrm{Zn}$ & $\mathrm{Cu}$ & Reference \\
\hline \multirow[t]{2}{*}{ Korea } & Kidney & & 5.18 & 0.19 & & & & Nam et al. (2006) \\
\hline & Liver & & 5.18 & 0.36 & & & & \\
\hline \multirow[t]{4}{*}{ London; Chelsea } & Intestine & & 22.20 & 0.82 & & 117.20 & & Hutton et al. (1980) \\
\hline & Kidney & & 32.14 & 12.30 & & 168.80 & & \\
\hline & Gizzard & & 5.60 & 0.31 & & 44.40 & & \\
\hline & Liver & & 21.60 & 2.45 & & 146.50 & & \\
\hline \multirow[t]{2}{*}{ The Netherlands } & Kidney & & 0.74 & 0.83 & & 9.15 & & Schilderman et al. (1997) \\
\hline & Liver & & 0.36 & 0.13 & & 10.85 & & \\
\hline \multirow[t]{5}{*}{ Spain } & Muscle & 0.06 & 0.11 & 0.01 & 0.61 & 12.22 & 4.02 & Torres et al. (2010) \\
\hline & Intestine & - & - & - & - & - & - & \\
\hline & Kidney & 0.19 & 0.29 & 0.68 & 0.51 & 25.02 & 2.84 & \\
\hline & Gizzard & - & - & - & - & - & - & \\
\hline & Liver & 0.06 & 0.29 & 0.11 & 0.52 & 40.91 & 3.41 & \\
\hline \multirow[t]{5}{*}{ Bangladesh } & Muscle & 0.03 & 0.39 & 0.03 & 0.91 & 145.69 & 26.09 & Present study \\
\hline & Intestine & 0.03 & 0.82 & 0.56 & 2.22 & 110.94 & 34.11 & \\
\hline & Kidney & 0.04 & 1.17 & 0.93 & 2.47 & 41.44 & 34.77 & \\
\hline & Gizzard & 0.03 & 0.54 & 0.53 & 1.49 & 117.91 & 36.53 & \\
\hline & Liver & 0.05 & 2.85 & 1.10 & 3.37 & 239.75 & 43.60 & \\
\hline
\end{tabular}

The Cr level in the muscle of C. livia, was $3.37 \mu \mathrm{g} / \mathrm{g}$, which is higher than the results observed by Torres et al. (2010). According to these results, it could be suggested that there is dense $\mathrm{Cr}$ pollution that might have resulted from the effluents from the tannery industries which has already reported (Mohanta et al. 2010; Ahmed et al. 2011) to have adversely affected the pigeon consumption by the local people.

In the present study, $\mathrm{Zn}$ concentration was found to be higher in the liver $(239.75 \mu \mathrm{g} / \mathrm{g})$, while the lowest concentration $(41.44 \mu \mathrm{g} / \mathrm{g})$ was detected in the kidney. Similar high concentration in liver $(\mathrm{Zn} 10.85 \mu \mathrm{g} / \mathrm{g})$ than in the kidney (Zn $9.15 \mu \mathrm{g} / \mathrm{g}$ ) (Schilderman et al. 1997) were reported previously. Zinc reached higher levels in the kidney than in the liver (Hutton et al. 1980), although our present value represent an opposite finding.
Copper concentrations averaged $(26.09 \mu \mathrm{g} / \mathrm{g})$ in the muscle, with the highest levels $(43.60 \mu \mathrm{g} / \mathrm{g})$ found in the liver (Table 2). A significantly higher level of $\mathrm{Cu}$ in the muscle than in the liver and intestine has been also observed (Torres et al. 2010). According to Pyle et al. (2005), $\mathrm{Cu}$ concentrations in liver are usually regulated by a homeostatic control below $50 \mu \mathrm{g} / \mathrm{g} \mathrm{dw}$ and can exceed this threshold only if the control mechanisms are overloaded. High $\mathrm{Cu}$ levels found in the present study (on average $35.02 \mu \mathrm{g} / \mathrm{g} \mathrm{dw}$ ) might imply loss of regulatory control of the liver.

Overall, the highest concentrations of $\mathrm{As}, \mathrm{Pb}, \mathrm{Cd}, \mathrm{Cr}$, and $\mathrm{Cu}$ were recorded in the liver, while the lowest ones were in the muscle except, Zn. Mormede and Davies (2001) suggested that the liver was the target organ, showing the detoxification and accumulation role of the 
liver. The muscle is generally considered to have a weak accumulating potential (Erdoğrul and Erbilir 2007; Uysal et al. 2009; Bervoets and Blust 2003). The liver is the preferred organ for metal accumulation which could also be deduced from the present study. This research showed that the intestine, kidney, gizzard, and liver have almost higher metal concentrations than the muscle. Such pattern has been observed in a number of other studies, covering a wide spectrum of pigeon (Torres et al. 2010; Nam et al. 2006; Schilderman et al. 1997). In Bangladesh, the recent average per capita consumption of fish/meat was 21 $\mathrm{g} /$ person/day for males and females of all ages (Begum et al. 2005).

Table 4. Comparison of the dietary intakes of metals from muscle of pigeon with the recommended dietary allowances.

\begin{tabular}{lcccccl}
\hline $\begin{array}{l}\text { Heavy } \\
\text { metal }\end{array}$ & $\begin{array}{c}\text { Average concentration } \\
\text { in muscle }(\mu \mathrm{g} / \mathrm{g} \text { dry } \\
\text { weight })\end{array}$ & $\begin{array}{c}\text { Estimated daily } \\
\text { intake }(\mathrm{mg} / \text { day/ } / \\
\text { person) }\end{array}$ & $\begin{array}{c}\text { Recommended daily } \\
\text { dietary allowance } \\
(\mathrm{mg} / \text { day/person) }\end{array}$ & $\begin{array}{c}\text { Reference } \\
\text { Contribution } \\
(\%)\end{array}$ & $\begin{array}{l}\text { Range of international } \\
\text { standard (Yamazaki et } \\
\text { al. 1996; } \mu \mathrm{g} / \mathrm{g} \text { fresh } \\
\text { weight) }\end{array}$ \\
\hline $\mathrm{As}$ & 0.03 & 0.0014 & $0.13^{\mathrm{a}}$ & JECFA 1989 & 1.08 & $0.1-5$ \\
$\mathrm{~Pb}$ & 0.39 & 0.0018 & $0.21^{\mathrm{a}}$ & JECFA 2000 & 0.86 & $0.5-10$ \\
$\mathrm{Cd}$ & 0.03 & 0.0001 & $0.06^{\mathrm{a}}$ & JECFA 1989 & 0.24 & $0.05-2$ \\
$\mathrm{Cr}$ & 0.91 & 0.0043 & $0.05-2^{\mathrm{b}}$ & NRC 1989 & $0.22-13.6$ & 1.0 \\
$\mathrm{Zn}$ & 145.69 & 0.69 & $18-60^{\mathrm{c}}$ & JECFA 1982 & $1.15-3.83$ & $40-100$ \\
$\mathrm{Cu}$ & 5.48 & 0.026 & $3-30^{\mathrm{c}}$ & JECFA 1982 & $0.08-0.87$ & $10-100$ \\
\hline
\end{tabular}

The average per capita consumption of muscle of pigeon was $21 \mathrm{~g}$ wet weight/person/day. Conversion factor (wet/dry weight) is 4.8 ${ }^{\mathrm{a}}$ Provisional tolerable intake $\left(60-\mathrm{kg}\right.$ body weight), ${ }^{\mathrm{b}}$ Estimated safe and adequate daily dietary intake, ${ }^{\mathrm{c}}$ Provisional maximum tolerable daily intake.

Since only the elemental concentration in the muscle of pigeon was measured in the present study, the overall dietary intake of elements from pigeon for Bangladeshi people cannot be estimated. However, in order to know the contribution of the dietary intake from pigeon to the recommended dietary allowance (RDA), we were forced to come up with an estimation using a calculation which employed the recent average per capita consumption (21 g). Compared to the RDA proposed by the NRC and the JECFA (JECFA 1982，1989，2000; NRC 1989), the estimated dietary intake from muscle of pigeon will constitute $0.22-13.6 \%$ (1.08\% for arsenic, $0.86 \%$ for cadmium, $0.24 \%$ for lead, and $13.6 \%$ for chromium), which is shown in Table 4. Therefore, it seems that the contributions of the dietary intake from pigeon to the RDA do not become a serious problem. The ranges of international standards (Yamazaki et al. 1996) are 0.1-5, $0.5-10,0.05-2$, and $1 \mu \mathrm{gg}^{-1}$ fresh weight of the muscle of pigeon for $\mathrm{As}, \mathrm{Pb}, \mathrm{Cd}$, and $\mathrm{Cr}$, respectively. The arsenic, lead, cadmium, and chromium contents in the muscle of pigeon corresponded to $0.006,0.08,0.006$, and $0.19 \mu \mathrm{g} / \mathrm{g}$ wet weight. This research showed that heavy metal concentrations in the muscle of pigeon were within the acceptable levels for human consumption. On the other hand, internal other organs had generally unacceptable heavy metal levels.

\section{Conclusion}

The concentrations of $\mathrm{As}, \mathrm{Pb}, \mathrm{Cd}, \mathrm{Cr}, \mathrm{Zn}$, and $\mathrm{Cu}$ in pigeon (C. livia) muscle tissue from studied sites were clearly below the limits of the International Standards compiled by the FAO of the United Nations. Thus, the edible tissue of pigeon from Bangladesh does not constitute any health risks for human consumers with respect to these elements. The liver appeared to be the main heavy metal storage tissue, while the muscle had the lowest levels of analyzed metals. The results confirmed that the pigeon muscle and the liver tissues appeared to be good model tissues for the identification of metallic contaminants. On the other hand, internal organs of pigeon like liver and kidney had generally unacceptable heavy metal levels which might still be a health hazard for a long period of accumulation. Therefore, further continuous monitoring of heavy metal contaminants in different tissues of pigeon will be needed in Bangladesh to ensure the safety of our consumers. 


\section{References}

Ahmed, K., Das, M., Islam, M.M., Akter, M.S., Islam, S. and AlMansur, M.A. 2011. Physico-chemical properties of tannery and textile effluents and surface water of River Buriganga and Karnatoli, Bangladesh. World Appl. Sci. J. 12, 152-159.

Begum, A., Amin, M.N., Kaneco, S. and Ohta, K. 2005. Selected elemental consumption of the muscle tissue of three species of fish, Tilapia nilotica, Cirrhina mrigala and Clarius batrachus, from the fresh water Dhanmondi Lake in Bangladesh. Food Chemistry, 93, 439-443.

Bervoets, L. and Blust, B. 2003. Metal concentrations in water, sediment and gudgeon (Gobio gobio) from a pollution gradient: relationship with fish condition factor. Environmental Pollution, 126, 9-19.

Burger, J. and Woolfenden, G.E. and Gochfeld, M. 1999. Metal concentrations in the eggs of endangered Florida scrub-jays from central Florida. Arch. Environ. Contam. Toxicol. 37, 385-8.

Cohen, J.B., Barclay, J.S., Major, A.R. and Fisher, J.P.. 2000. Wintering greater scaup as biomonitors of metal contamination in federal wildlife refuges in the Long Island region. Arch. Environ. Contam. Toxicol. 38, 83-92.

Cohen, T., Hee, S. and Ambrose, R. 2001. Trace metals in fish and invertebrates of three California coastal wetlands. Marine Pollution Bulletin, 42, 224-232.

Nam, Dong-Ha and Lee, Doo-Pyo 2006. Monitoring for $\mathrm{Pb}$ and $\mathrm{Cd}$ pollution using feral pigeons in rural, urban, and industrial environments of Korea, Science of the Total Environment, 357, 288-295.

Eens M, Pinxten R, Verheyen RF, Blust R. and Bervoets L. 1999. Great and blue tits as indicators of heavy metal contamination in terrestrial ecosystems. Ecotoxicol Environ Saf. 44, 81-85.

Erdoğrul, Ö. and Erbilir, F. 2007. Heavy metal and trace elements in various fish samples from Sir Dam Lake, Kahramanmaraş, Turkey. Environmental Monitoring and Assessment, 130, 373-379.

EUCommission 2001. EUCommissionRegulation as regards heavy metals. Directive 2001/22/EC, No. 466/2001/EEC as amended by regulation 221/2002/EC. Brussels: EU Commission.

Hutton, M. and Goodman G.T. 1980. Metal contamination of feral pigeons Columba livia from London area: Part I. Tissue accumulation of lead, cadmium and zinc. Environ Pollut A, 22, 207-17.

JECFA 1982. Evaluation of certain food additives and contaminants. Twenty-sixth report of the joint FAO/WHO Expert Committee on Food Additives (WHO technical report series, no. 683), World Health Organization, Geneva.

JECFA (1989). Evaluation of certain food additives and contaminants. Thirty-third report of the joint FAO/WHO
Expert Committee on Food Additives (WHO technical report series, no. 776), World Health Organization, Geneva.

JECFA 2000. Evaluation of certain food additives and contaminants. Fifty-third report of the joint FAO/WHO Expert Committee on Food Additives (WHO technical report series, no. 896), World Health Organization, Geneva.

Mohanta, M.K., Salam, M.A., Saha, A.K., Hasan, A. and Roy, A. K. 2010. Effects of tannery effluents on survival and histopathological changes in different organs of Channa punctatus. Asian J. Experimental Biol. Sci. 1, 294-302.

Mormede, S. and Davies, I.M. 2001. Heavy metal concentrations in commercial deep-sea fish from the Rockall Trough. Continental Shelf Res. 21, 899-916.

Nam D.H., Lee D.P. and Koo T.H. 2004. Factors causing variations of lead and cadmium accumulation of feral pigeons (Columba livia). Environ. Monit. Assess. 95, 2335 .

NRC. 1989. National research council recommended dietary allowances (10th ed., pp. 241-243). Washington, DC: National Academy of Sciences.

Olojo, E.A.A., Olurin, K.B., Mbaka, G. and Oluwemimo, A.D. 2005. Histopathology of the gill and liver tissues of the African catfish Clarias gariepinus exposed to lead. African J. Biotechnol. 4, 117-122.

Pyle, G.G., Rajotte, J.W. and Couture, P. 2005. Effects of industrial metals on wild fish populations along a metal contamination gradient. Ecotoxicol. Environ. Safety 61, 287-312.

Schilderman P.A.E.L, Hoogewerff, J.A., Schooten F-J, Maas L.M., Moonen E.J.C. and Os B.J.H., 1997. Possible relevance of pigeons as an indicator species for monitoring air pollution. Environ. Health Perspect. 105, 322-329.

Singh, R.K., Chavan, S.L. and Sapkale, P.H. 2007. Heavy metal concentrations in water, sediments and body tissues of red worm (Tubifex spp.) collected from natural habitats in Mumbai, India. Environmental Monitoring and Assessment, 129, 471-481.

Stoica, A., Pentecost, E. and Martin, M.B. 2000. Effects of arsenite on estrogen receptor-alpha expression and activity in MCF-7 breast cancer cells. Endocrinology, 141, 35953602.

Storelli, M.M., Barone, G., Storelli, A. and Marcotrigiano, G. O. 2006. Trace metals in tissues of mugilids (Mugil auratus, Mugil capito, and Mugil labrosus) from the Mediterranean Sea. Bulletin of Environmental Contamination and Toxicology, 77, 43-50.

Sundlof, S.F., M.G. Spalding, J.D. Wentworth, and C.K. Steible. 1994. Mercury in livers of wading birds (Ciconiiformes) in southern Florida. Arch. Environm. Contam. Toxicol. 27, 299-305. 
Torres J., Foronda P., Eira C., Miquel J. and Feliu C. 2010. Trace element concentrations in Raillietina micracantha in comparison to its definitive host, the feral pigeon Columba livia in Santa Cruz de Tenerife (Canary Archipelago, Spain). Arch. Environ. Contam. Toxicol. 58, 176-182

Uysal, K., Köse, E., Bülbül, M., Dönmez, M., Erdoğan, Y., Koyun, M., Ömeroğlu, Ç. and Özmal, F. 2009. The comparison of heavy metal accumulation ratios of some fish species in Enne Dame Lake (Kütahya/Turkey). Environ. Monitor. Assess. 157, 355-362.
Yamazaki, M., Tanizaki, Y. and Shimokawa, T. 1996. Silver and other trace elements in a freshwater fish, Carasius auratus langsdorfii, from the Asakawa River in Tokyo, Japan. Environ. Poll. 94, 83-90. 